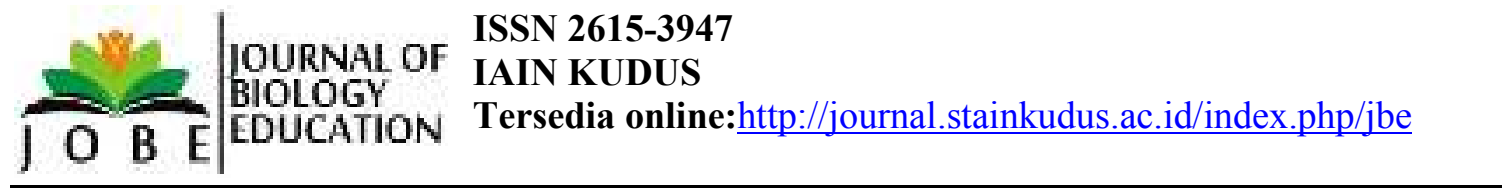

\title{
PERBANDINGAN PENGARUH PUASA DAUD DAN PUASA SENIN-KAMIS TERHADAP KADAR KOLESTEROL PADA MENCIT
}

\author{
Nurul Marfu'ah ${ }^{1}$, Dianti Desita Sari² \\ (1), (2) UNIVERSITAS DARUSSALAM GONTOR PONOROGO \\ (1) $\underline{\text { nurulmarfuah@unida.gontor.ac.id, }}{ }^{(2)}$ diantids@unida.gontor.ac.id
}

\begin{abstract}
ABSTRAK
Kadar kolesterol di dalam darah di atas kadar normal disebut dengan hiperkolesterolemia. Kondisi ini akan menyebabkan banyak penyakit seperti atherosklerosis, penyakit hati dan stroke. Cara pencegahan yang dianjurkan adalah dengan berpuasa. Oleh karena iu, penelitian ini bertujuan untuk mengetahui pengaruh puasa terhadap kadar kolesterol. Penelitian ini menggunakan rancangan acak lengkap. Penelitian ini menggunakan mencit umur 8-10 minggu dan berat 2326 gram. Perlakuan A, tidak berpuasa sebagai kontrol, B puasa Senin-Kamis, C Puasa Daud. Perlakuan dilakukan selama 36 hari, kemudian diukur kadar kolesterol dalam darah mencit. Analisis data menggunakan one way ANOVA dengan taraf signifikansi 5\%. Hasil menunjukkan bahwa tingkat signifikansi $>0,05$ yang berarti puasa Senin-Kamis dan Puasa Daud tidak berpengaruh nyata terhadap kadar kolesterol dalam darah mencit.
\end{abstract}

Kata Kunci: Kolesterol, puasa Daud, Senin-Kamis

\begin{abstract}
Cholesterol level in the blood above normal level are called hypercholesterolemia. This condition will cause many diseases such as atherosclerosis, heart disease and stroke. Recommended method to prevent this disease is doing fasting. Therefore, this study aims to determine the effect of fasting on cholesterol levels. This research is an experiment with Complete Random Design (CRD) method. The experimental were use mice aged 8-10 weeks and weight 23-26 grams. The treatment are (A) not fasting as a control, (B) fasting Monday-Thursday, (C) fasting Daud. The treatment was given for 36 days then cholesterol levels were measured from the blood of the mice. The data were analyzedby one way ANOVA SPSS statistical program with $5 \%$ significance level. The results showed that the sig value $>0.05$, which means that the fasting Monday-Thursday and Daud did not affected the cholesterol levels in mice.
\end{abstract}

Keywords: Cholesterol,Daud, Fasting, Monday-Thursday 


\section{PENDAHULUAN}

Kolesterol merupakan substansi lemak hasil metabolisme yang banyak ditemukan di dalam darah serta cairan empedu (Frandson, 1992). Selain itu, terdapat juga pada hati, daging, otak, kuning telur, usus, ginjal, lemak hewan, darah, jaringan urat saraf, dan kortilis adrenal (Harper et. al., 1979). Kolesterol dalam darah kadarnya mencapai 14\%. Kolesterol diangkut dalam plasma darah sebagai lipoprotein. Empat kelompok utama lipoprotein penting yaitu kilomikron, VLDL, LDL dan HDL. Kilomikron mengangkut lipid yang dihasilkan dari pencernaan dan penyerapan; VLDL mengangkut triasilgliserol dari hati; LDL menyalurkan kolesterol ke jaringan, dan HDL membawa kolesterol ke jaringan dan mengembalikannya ke hati untuk diekskresikan (Murray et. al., 2003).

Kadar kolesterol dalam darah dipengaruhi oleh konsumsi makanan, umur, jenis kelamin, dan konsumsi asam lemak tidak jenuh (Frandson, 1992). Fungsi kolesterol dalam tubuh adalah sebagai prekursor pembentuk asam empedu yang disintesis di dalam hati yang berfungsi untuk menyerap trigliserida dan vitamin yang larut dari makanan. Kolesterol juga berfungsi sebagai prekursor dari berbagai jenis hormon steroid. Dalam keadaan normal, kolesterol dibutuhkan tubuh dalam membentuk membran sel, struktur insulin otak, sistem saraf pusat, dan vitamin D (Murray et al., 2003). Sumber kolesterol dapat berasal dari makanan yang disebut eksogen dan biosintesis de novo yang dibentuk pada sel tubuh (Guyton, 1996).

Kadar kolesterol dalam darah yang berada di atas normal ( $\geq 200 \mathrm{mg} / \mathrm{dL}$ ) disebut hiperkolesterolemia (Panagiotakos, 2007). Timbunan lemak di dalam pembuluh darah (plak kolesterol) menyebabkan pembuluh darah menjadi menyempit, kaku dan aliran darah kurang lancar yang disebut sebagai arterosklerosis. Arterosklerosis pada jantung akan menyebabkan penyakit jantung, sedangkan jika terjadi di arteri yang menuju ke otak akan menyebabkan stroke (Waspaji, 2003).

Menurut artikel yang ada dalam Tribunnews (2016), beberapa ciri orang terkena penyakit kolesterol adalah:

\section{Kesemutan}

Biasanya kesemutan terjadi karena duduk terlalu lama dalam posisi yang tidak berubah, sering merasa kesemutan merupakan salah satu ciri dari 
penyakit kolesterol tinggi, maka dari itu apabila anda mengalami sering kesemutan maka anda harus segera melakukan pemeriksaan.

2. Sering mual dan muntah

Mual dan muntah ini terjadi karena saluran pencernaan mengalami gangguan, penyakit kolesterol tinggilah yang menyebabkan terjadinya gangguan pada saluran pencernaan, biasanya dampak yang akan ditimbulkan adalah seringnya mual dan muntah.

3. Hilangnya keseimbangan

Biasanya orang yang menderita kolesterol tinggi akan mengalami rasa tidak nyaman, kondisi tersebut biasanya mengakibatkan hilangnya keseimbangan, apabila kondisi ini terjadi biasanya otot otot akan menjadi lemah.

4. Mengalami nyeri leher dan punggung

Orang yang menderita kolesterol tinggi juga biasanya akan mengalami nyeri pada area leher dan punggung, kondisi ini disebabkan oleh munculnya tekanan darah tinggi yang muncul secara bersamaan.

5. Tubuh yang sangat lelah

Biasanya orang yang menderita penyakit kolesterol tinggi akan mengalami kekurangan pasokan aliran darah dan juga kekurangan oksigen, kondisi seperti ini bisa menimbulkan dampak tubuh akan menjadi lemah.

6. Mengalami sakit kaki dan tangan

Selain akan mengalami nyeri leher dan punggung, orang yang mengalami kolesterol tinggi juga akan mengalami rasa sakit pada kaki dan tangan, apabila anda mengalami kondisi seperti ini segera lakukan pemeriksaan.

7. Emosi yang tidak stabil

Ciri yang satu ini mungkin masih jarang diketahui oleh orang kebanyakan, perlu anda ketahui orang yang mengalami kolesterol tinggi biasanya akan mengalami perbuahan emosi, seperti mudah sekali untuk marah padahal penyebabnya adalah hal yang sepele.

8. Wajah merah 
Pada kasus yang serius terutama orang yang menderita penyakit hipertensi, biasanya akan berdampak pada membesarnya pembuluh darah, yang mana kondisi tersebut bisa menyebabkan wajah orang yang mengalaminya akan menjadi merah.

\section{Sakit kepala}

Meraskan sakit kepala ini biasanya lebih sering terjadi pada orang yang menderita penyakit hipertensi atau darah tinggi yang mana kondisi tekanan darahnya sudah sangat tinggi, maka dari itu apabila anda mengalami kondisi seperti ini kemungkinan besar anda mengalami kolesterol tinggi.

10. Otot kaki lemah

Mengalami lemah pada otot kaki juga merupakan salah satu ciri dari penyakit kolesterol tinggi, kondisi seperti ini biasanya disebabkan karena kurangnya pasokan darah ke otot kaki sehingga mengakibatkan otot kaki menjadi lemah.

\section{Sulit bernafas}

Pada umumnya mengalami kesulitan untuk bernafas merupakan salah satu ciri umum penyakit asma, namun mengalami kesulitan bernafas merupakan salah satu ciri dari penyakit kolesterol tinggi yang harus anda waspadai.

\section{Nyeri dada}

Ciri-ciri terakhir orang yang mengalami penyakit kolesterol tinggi adalah sering mengalami nyeri pada ada, nah apabila anda mengalami kondisi seperti ini segera lakukan pemeriksaan agar tingkat kadar kolesterol tidak menjadi tambah tinggi.

Beberapa makanan yang harus dihindari apabila seseorang mengalami kolesterol tinggi, diantaranya adalah:

1. Goreng-gorengan dan mentega.

2. Susu lemak tinggi, sosis atau keju.

3. Gajih sapi, gajih kambing, dan daging sapi berlemak.

4. Kepiting, kerang, udang, belut, siput memiliki kadar kolesterol yang tinggi.

Menurut Survey Kesehatan Rumah Tangga (SKRT), prevalensi hiperkolesterolemia di Indonesia pada usia $\geq 25$ tahun adalah 13,6\% (laki-laki 19,2\% dan wanita 16,7\%) (Balitbangkes, 2004). Pengobatan hiperkolesterolemia 
dengan obat sintetik banyak dipilih, walaupun efektif namun dapat menimbulkan efek samping yang berbahaya seperti gangguan fungsi ginjal, hati, dan paru-paru (Hicow, 2011). Beberapa penelitian telah dilakukan untuk mengatasi penyakit hiperkolesterolemia ini, di antaranya dengan penggunaan obat herbal atau dengan perlakuan secara non farmakologis misalnya dengan puasa.

Puasa adalah salah satu ibadah yang dilakukan umat Muslim. Menurut istilah, puasa berarti menahan, berpantang, atau mengendalikan diri dari makan, minum, bersetubuh, dan hal-hal lain yang membatalkan diri dari terbit fajar hingga terbenam matahari (Syarifuddin, 2003). Sedangkan Susetya (2007) menjelaskan bahwa puasa ada yang bersifat wajib seperti puasa Romadhon, ada pula yang bersifat sunnah (jika dikerjakan mendapat pahala, jika ditinggalkan tidak mendapat dosa) seperti:

1. Puasa hari Senin dan Kamis

Rasulullah SAW bersabda: "Berbagai amalan dihadapkan (pada Allah) pada hari Senin dan Kamis, maka aku suka jika amalanku dihadapkan sedangkan aku sedang berpuasa" (HR. Tirmidzi).

2. Puasa Daud

Puasa Daud adalah puasa sunnah yang biasa dikerjakan oleh Nabi Daud. Puasa dikerjakan dengan cara sehari puasa dan sehari tidak. Rasulullah SAW berkata epada Abdullah bin 'Amru bin Al 'Ash: "Berpuasalah dengan puasanya Nabi Allah Daud Alaihissalam dan jangan kamu tambah lebih dari itu". Aku bertanya: "Bagaimanakah cara puasanya Nabi Allah Daud Alaihissalam?" Beliau menjawab: "Dia berpuasa setengah dari puasa Dahr (puasa sepanjang tahun) (caranya yaitu sehari puasa dan sehari tidak)" (HR.Bukhari).

Menurut Saleh (2009), jenis-jenis puasa (shaum) dibedakan menjadi:

1. Shaum Wajib

a. Puasa Ramadhan (QS 2/183) atau penggantinya (QS 2/184). •

b. Puasa nadzar, yaitu janji kepada Allah SWT untuk berpuasa (HR Abu Daud).

c. Puasa kiffarah, diantaranya karena melanggar sumpah atau hajji tamattu' (HR Jama'ah).

2. Shaum Sunnah 
a. Puasa Senin - Kamis (HR Muslim dan Abu Daud no.7439).

b. Puasa 6 hari di bulan Syawwal (HR Jama'ah kecuali Bukhari dan Nasa'i) ·

c. Puasa 9 Dzulhijjah/puasa Arafah (HR Muslim). •

d. Puasa ayyamil bidh, yaitu pada tanggal 13, 14, 15 setiap bulan Hijriah (HR Bukhari Muslim, al-Lu'lu wal Marjan, no.418).

e. Puasa Asyura dan Tasu'a, yaitu tanggal 9 dan 10 Muharram (HR Bukhari Muslim).

f. Puasa di bulan Sya'ban (HR Nasa'i dll.) ·

g. Puasa di bulan-bulan haram (suci) yaitu : Dzul qa'dah, Dzulhijjah, Muharram dan Rajab tanpa mengkhususkan pada hari-hari tertentu (HR Abu Daud no. 2428; Ibnu Majah no.1741 dan Nasa'i).

h. Puasa Daud, yaitu berpuasa berselang sehari setiap waktu (HR Bukhari Muslim dan lainnya)

3. Shaum Haram

a. Puasa pada 2 hari Raya (HR Bukhari Muslim) dan hari Tasyrik : 11, 12, 13 Dzulhijjah (HR Muslim). •

b. Puasa wishal (yaitu sampai lewat maghrib), (HR Bukhari Muslim) seperti : Tapa, ngebleng, pati geni, mutih, ngalang, ngeplang, kungkum dan berbagai puasa bid'ah lainnya. •

c. Puasa wanita yang nifas atau haidh (HR Jama'ah). •

d. Puasa yang membahayakan kondisi fisik (QS 2/195). •

e. Puasa sunnah wanita dirumah suami tanpa izin suami (HR Bukhari Muslim).

\section{Shaum Makruh}

a. Puasa dengan mengkhususkan hari-hari tertentu tanpa sebab qadha' (HR Ahmad dan Nasa'i), seperti 12 rabi'ul awwal, 27 Rajab, nishfu Sya'ban dll (lih. Zadul Ma'ad dalam al-Qardhawi hal. 186-188).

b. Puasa sepanjang masa (HR Bukhari Muslim).

c. Puasa hari Jum'at (HR Bukhari Muslim) atau Sabtu (HR Muslim), jika tanpa sebab qadha'. 
Menurut Saleh (2009), syarat puasa terbagi menjadi dua macam. Pertama adalah syarat wajib puasa, dimana bila syarat-syarat ini terpenuhi, seeorang menjadi wajib hukumnya untuk berpuasa.Kedua adalah syarat syah puasa, dimana seseorang syah puasanya bila memenuhi syarat-syarat itu. Syarat-syarat puasa yaitu:

1. Syarat Wajib

Syarat wajib maksudnya adalah hal-hal yang membuat seorang menjadi wajib untuk melakukan puasa.Bila salah satu syarat ini tidak terpenuhi pada diri seseorang, maka puasa Ramadhan itu menjadi tidak wajib atas dirinya.Meski kalau dia mau, dia tetap diperbolehkan untuk berpuasa. Diantara syarat-syarat yang mewajibkan seseorang harus berpuasa antara lain yaitu :

a. Baligh

Anak kecil yang belum baligh tidak wajib puasa.Namun orang tuanya wajib memerintahkannya puasa ketika berusia 7 tahun dan bila sampai 10 tahun boleh dipukul.Persis seperti pada masalah shalat. Rasulullah SAW bersabda : Dari Ibnu Amr bahwa Rasulullah SAW bersabda,"Perintahkan anak-anak kamu untuk mengerjakan shalat ketika berusia 7 tahun dan pukullah mereka karena tidak menegakkan shalat ketika berusia 10 tahun", (HR. Abu Daud dan Hakim dan dishahihkan dalam Al-Jamius Shaghir). Meski demikian, secara hukum anak-anak termasuk yang belum mendapat beban/taklif untuk mengerjakan puasa Ramadhan, sebagaimana yang disebutkan dalam hadits "telah diangkat pena dari tiga orang : Dari orang gila hingga waras, dari orang yang tidur hingga terjaga dan dari anak kecil hingga mimpi"'(HR. Ahmad, Abu Daud dan Tirmizy).

b. Berakal

Orang gila tidak wajib puasa bahkan tidak perlu menggantinya atau tidak perlu mengqadha 'nya.Kecuali bila melakukan sesuatu secara sengaja yang mengantarkannya kepada kegilaan, maka wajib puasa atau wajib menggantinya. Hal yang sama berlaku pada orang yang mabuk, bila mabuknya disengaja. Tapi bila mabuknya tidak disengaja, maka tidak wajib atasnya puasa.

c. Sehat 
Orang yang sedang sakit tidak wajib melaksanakan puasa Ramadhan. Namun dia wajib menggantinya di hari lain ketika nanti kesehatannya telah pulih. Allah SWT berfirman :...Dan barangsiapa sakit atau dalam perjalanan, maka (wajib menggantinya) sebanyak hari yang ditinggalkannya itu pada hari-hari yang lain. Allah menghendaki kemudahan bagimu, dan tidak menghendaki kesukaran bagimu...(QS. AlBaqarah : 185). Jenis penyakit yang membolehkan seseorang tidak menjalankan kewajiban puasa Ramadhan adalah penyakit yang akan bertambah parah bila berpuasa. Atau ditakutkan penyakitnyaakan terlambat untuk sembuh.

d. Mampu

Allah hanya mewajibkan puasa Ramadhan kepada orang yang memang masih mampu untuk melakukannya.Sedangkan orang yang sangat lemah atau sudah jompo dimana secara fisik memang tidak mungkin lagi melakukan puasa, maka mereka tidak diwajibkan puasa. Allah SWT berfirman :Dan wajib bagi orang-orang yang berat menjalankannya membayar fidyah, yaitu memberi makan seorang miskin...(QS. Al-Baqarah : 184)

e. Tidak dalam perjalanan (bukan musafir)

Orang yang dalam perjalanan tidak wajib puasa.Tapi wajib atasnya mengqadha` puasanya. Dalam hadits Rasulullam SAW disebutkan : Bahwa Hamzah Al-Aslami berkata,"Ya Rasulallah, Aku kuat tetap berpuasa dalam perjalanan, apakah aku berdosa ?". Rasulullah SAW menjawab, "Itu adalah keringanan dari Allah Ta 'ala, siapa yang berbuka maka baik. Dan siapa yang lebih suka berpuasa maka tidak ada dosa".(HR. Muslim).

2. Syarat Syah

Syarat syah adalah syarat yang harus dipenuhi agar puasa yang dilakukan oleh seseorang itu menjadi syah hukumnya di hapadan Allah SWT. Syarat syah puasa adalah:

a. Niat

Bila seseorang berpuasa tapi lupa atau tidak berniat, maka puasanya tidak syah.Maksudnya puasa wajib bulan Ramadhan atau puasa wajib nazar atau 
puasa wajib qadha'. Namun bila puasa sunnah, maka niatnya tidak harus sejak terbit fajar, boleh dilakukan di siang hari ketika tidak mendapatkan makanan.

b. Beragama Islam

c. Puasa orang bukan muslim baik kristen, katolik, hindu, budha atau agama apapun termasuk atheis tidak syah. Bila mereka tetap berpuasa, maka tidak mendapatkan balasan apa-apa.

d. Suci dan haidh dan nifas

Wanita yang mendapat haidh dan nifas, bila tetap berpuasa, maka puasanya tidak syah.

e. Pada hari yang dibolehkan puasa

Bila melakukan puasa pada hari-hari yang dilarang, maka puasanya tidak syah bahkan haram untuk dilakukan.

Menurut Saleh (2009), puasa itu mempunyai dua rukun yang menjadi inti dari ibadah tersebut. Tanpa kedua hal itu, maka puasa menjadi tidak berarti. Rukun puasa yaitu:

1. Niat

Niat adalah azam (berketatapan) di dalam hati untuk mengerjakan puasa sebagai bentuk pelaksanaan perintah Allah SWT dan taqarrub (pendekatan diri) kepada-Nya. Sabda Rasulullah SAW : Sesungguhnya semua amal itu tergantung niatnya. Kedudukan niat ini menjadi sangat penting untuk puasa wajib.Karena harus sudah diniatkan sebelum terbit fajar.Dan puasa wajib itu tidak syah bila tidak berniat sebelum waktu fajar itu. Sabda Rasulullah SAW : Barang siapa yang tidak berniat pada malamnya, maka tidak ada puasa untuknya (HR. Tirmizi). Berbeda dengan puasa sunnah yang tidak mensyaratkan niat sebelum terbit fajar. Jadi boleh berniat puasa meski telah siang hari asal belum makan, minum atau mengerjakan sesuatu yang membatalkan puasa. Hal tersebut sesuai dengan apa yang dilakukan oleh Rasulullah SAW. Dari Aisyah RA. Berkata, Rasulullah SAW datang kepadaku pada suatu hari dan bertanya, "Apakah kamu punya makanan ?". Aku menjawab,"Tidak".Beliau lalu berkata,"Kalau begitu aku berpuasa" (HR. Muslim). 
2. Imsak (menahan)

Imsak artinya menahan dari makan, minum, hubungan seksual suami istri dan semua hal yang membatalkan puasa, dari sejak fajar hingga terbenamnya matahari. Allah SWT berfirman :...Maka sekarang campurilah mereka dan ikutilah apa yang telah ditetapkan Allah untukmu, dan makan minumlah hingga terang bagimu benang putih dari benang hitam, yaitu fajar. Kemudian sempurnakanlah puasa itu sampai malam...(QS. Al-Baqarah : 187).Yang dimaksud dengan benang putih dan benang hitam adalah putihnya siang dan hitamnya malam.

Menurut Saleh (2009), hal-hal yang membatalkan puasa adalah:

1. Makan minum secara sengaja

Bila makan dan minum secara sengaja, maka batallah puasanya.Tetapi bila makan dan minum karena lupa, maka tidak membatalkan puasa, asal ketika ingat segera berhenti dari makan dan minum.Termasuk yangmembatalkan puasa adalah makan atau minum dengan menyangka bahwa belum terbit fajar, padahal sudah terbit, maka batallah puasanya.Dan makan atau minum dengan menyangka sudah masuk waktu berbuka, padahal ternyata belum, maka puasanya pun batal.Termasuk batal juga bila makan atau minum karena lupa tetapi begitu ingat, tidak berhenti dari makan atau minum.Apabila seseorang memasukkan benda ke dalam tubuhnya melalui lubang seperti hidung, mulut, mata, telinga secara sengaja, maka batal pula puasanya. Sabda Rasulullah SAW Dari Abi Hurairah ra bahwa Rasulullah SAW bersabda, "Siapa lupa ketika puasa lalu dia makan atau minum, maka teruskan saja puasanya. Karena sesungguhnya Allah telah memberinya makan dan minum(HR. Jamaah). Sabda Rasulullah SAW Dari Abi Hurairah ra bahwa Rasulullah SAW bersabda,"Siapa yang berbuka pada saat Ramadhan karean lupa, tidak ada keharusan mengqadha`atau membayar kafarah (HR. Muslim).

2. Hubungan seksual

Hubungan seksual suami istri membatalkan puasa.Dan bila dikerjakan pada saat puasa Ramadhan, maka selain membayar qadha' juga diwajibkan membayar kaffarah.Karena hubungan seksual di siang hari bulan Ramadhan termasuk perbuatan yang merusak kesucian Ramadhan itu.Padahal kita 
diperintahkan pada saat-saat itu untuk menahan segala nafsu dan dorongan syahwat dengan tidak makan, tidak minum dan tidak melakukan hal-hal yang keji dan mungkar.Tetapi justru pada saat yang semulia itu malah melakukan hubungan seksual di siang hari. Karena itu hukumannya tidak hanya mengganti/mengqadha' puasa di hari lain, tetapi harus membayuar denda/kaffarah sebagai hukuman dari merusak kesucian bulan Ramadhan. Bentuk kaffarah itu salah satu dari tiga hal : a. Memerdekakan budak b. Puasa 2 bulan berturut-turut c. Memberi makan 60 orang miskin.

3. Sengaja muntah

Istiqa' atau muntah adalah bila seseorang melakukan sesuatu yang mengakibatkan muntah, maka puasanya batal.Seperti memasukkan jari ke dalam mulut tidak karena kepentingan.Atau membuang lendir dari tenggorokan tetapi malah mengakibatkan muntah.Dan semua pekerjaan lainnya yang pada dasrnya tidak perlu dilakukan tetapi malah mengakibatkan muntah.Semua itu dapat membatalkan puasa karena itu harus dihindari agar tidak melakukannya saat berpuasa.Namun bila muntah karena sebab yang tidak bisa ditolak seperti karena masuk angin atau sakit lainnya, maka puasanya tetap syah.Sabda Rasulullah SAW, "Siapa yang menyngaja muntah, wajiblah mengganti (mengqadha') puasanya”.

4. Hilang/berubah niatnya

Ketika seseorang dalam keadaan puasa, lalu terbetik dalam hatinya niat untuk berbuka saat itu juga sehingga niat puasanya menjadi hilang atau berubah, maka puasanya telah batal.Meskipun saat itu dia belum lagi makan atau minum.Karena niat merupakan rukun puasa.Bila niat itu hilang, maka hilang pula puasanya.Karena itu niat harus terpasang terus ketika berpuasa dan tidak boleh berubah.Niat itu adalah azam atau tekad.Tekad itu harus ada terus selama menjalankan ibadah puasa.Hilangnya tekan maka hilang pula nilai ibadahnya.

5. Murtad

Seseorang yang sedang berpuasa, lalu keluar dari agama Islam/murtad, maka otomatis puasanya batal.Dan bila hari itu juga dia kembali lagi masuk Islam, puasanya sudah batal.Dia wajib mengqadha puasanya hari itu meski belum sempat makan atau minum.Fiman Allah SWT, "Bila kamu menyekutukan 
Allah (murtad), maka Allah akan menghapus amal-amalmu dan kamu pasti jadi orang yang rugi” (QS Az-Zumar).

6. Keluarnya mani secara sengaja

Melakukan segala sesuatu yang dapat merangsang birahi hingga sampai keluar air mani menyebabkan puasa menjadi batal. Seperti melakukan onani/masturbasi, atau melihat gambar porno baik media cetak maupun film dan internet. Bahkan bila seseorang dalam keadaan puasa lalu berfantasi dan berimajinasi seksual yang mengakibatkan keluarnya mani, maka puasanya batal dengan sendirinya. Termasuk bercumbu antara suami istri yang mengakibatkan keluarnya mani meski tidak melakukan hubungan seksual, maka puasanya batal meski tidak sampai wajib membayar kaffarah. Karena itu sebaiknya hindari semua hal yang merangsang birahi karena beresiko batalnya puasa. Tetapi bila keluar mani dengan sendirinya seperti bermimpi, maka puasanya tidak batal, karena bukan disengaja atau bukan kehendaknya. Sabda Rasulullah SAW, "Telah diangkat pena dari tiga orang ; orang gila hingga waras, orangtidur hingga bangun dan anak kecil hingga baligh”.

7. Mendapat Haidh atau Nifas

Wanita yang sedang berpuasa lalu tiba-tiba mendapat haidh, maka otomatis puasanya batal.Meski kejadian itu menjelang terbenamnya matahari.Begitu juga wanita yang mendapat darah nifas, maka puasanya batal.Ini adalah merupakan ijma` para ulama Islam atas masalah wanita yang mendapat haidh atau nifas saat sedang berpuasa.

Menurut Judarmanto (2012), manfaat puasa antara lain keseimbangan anabolisme dan katabolisme, tidak mengakibatkan pengasaman dalam darah, penurunan glukosa darah dan berat badan. Mengendalikan kadar HDL dan LDL dalam darah, memperbaiki fungsi dan kinerja sel, sangat efektif meningkatkan konsentrasi urin, meningkatkan sistem kekebalan tubuh (meningkatkan kadar limfosit T), bermanfaat dalam pembentukan sperma, memperbaiki kadar hormon testosteron dan performa seksual, memperbaiki kondisi mental, meningkatkan komunikasi psikososial baik dengan Allah dan sesama manusia, serta menurunkan adrenalin. Keadaan psikologis yang tenang dan tidak dipenuhi rasa amarah saat puasa dapat menurunkan adrenalin. Adrenalin dapat meningkatkan tekanan darah, 
meningkatkan detak jantung, meningkatkan pembentukan kolesterol yang dapat menyebabkan risiko penyakit pembuluh darah, jantung koroner dan stroke.

Penelitian mengenai manfaat puasa Senin-Kamis dan Daud telah dilakukan di antaranya adalah penelitian Purwaningsih (2007) menunjukkan bahwa puasa Senin Kamis dapat meningkatkan suhu tubuh. Penelitian Kurniawati (2010) menunjukkan bahwa puasa sunnah Daud dan Senin-Kamis juga dapat meningkatkan motivasi berprestasi pada siswa. Menurut penelitian Fathonah (2011), puasa Daud dapat menstabilkan emosi manusia. Menurut Irchamni (2011), puasa Senin-Kamis dapat menurunkan tingkat kecemasan pada manusia. Sedangkan menurut Saputra (2016) hasil penelitiannya menunjukkan bahwa puasa Senin-Kamis dapat menurunkan kadar gula dalam darah. Perbandingan perlakuan puasa Senin-Kamis dan Daud terhadap kadar kolesterol pada Mencit belum pernah dilakukan. Oleh karena itu, penelitian ini penting untuk dilakukan.

\section{METODE PENELITIAN}

Penelitian ini merupakan penelitian eksperimen dengan rancangan penelitian Rancangan Acak Lengkap (RAL) menggunakan 3 perlakuan dan 3 ulangan. Masing-masing ulangan terdiri dari 2 ekor mencit, sehingga diperlukan 18 ekor mencit sebagai hewan percobaan. Perlakuan yang dilakukan meliputi (A) Tidak Puasa (Kontrol) (B) Puasa Senin-Kamis dan (C) Puasa Daud.

Penelitian ini dimulai dengan mengadaptasikan mencit dengan tempat perlakuan (aklimatisasi) selama 1 minggu. Mencit ditempatkan dalam 18 kandang (setiap kandang berisi 1 ekor) yang terbuat dari bak plastik dikelilingi kasa kawat, dan diberi alas serutan kayu yang diganti setiap 4 hari sekali. Mencit diberi pakan berupa pellet dan minuman air ledeng yang diberikan secara ad libitum. Mencit ditimbang setiap hari menggunakan timbangan digital untuk mengetahui berat badan sebelum diberi perlakuan. Mencit bukan kontrol kemudian dipuasakan (tidak diberi makan dan tidak diberi minum) mulai pukul 04.00 WIB sampai 18.00 WIB selama 36 hari. Kelompok 6 ekor mencit dipuasakan setiap Senin dan Kamis, 6 ekor lainnya dipuasakan selang satu hari (Daud). Darah mencit diambil melalui vena pembuluh bagian ekor kemudian diletakkan pada strip kolesterol (glucometer) kemudian diamati kadar kolesterolnya. Data dianalisis menggunakan one-way 
ANOVA dengan taraf signifikansi 5\%. Apabila hasilnya menunjukkan nilai signifikan, analisis diteruskan dengan uji Post Hoc LSD. Program statistik yang digunakan untuk analisis adalah program SPSS 20.

\section{HASIL DAN PEMBAHASAN}

Data mengenai rata-rata kadar kolesterol mencit disajikan pada Tabel 1. Berdasarkan hasil analisis menunjukkan bahwa nilai sig. rata-rata kadar kolesterol mencit adalah 0,251 yang berarti rata-rata kadar kolesterol mencit antar kelompok perlakuan secara statistik tidak berbeda nyata $(\mathrm{P}>0,05)$. Meskipun demikian, ratarata kadar kolesterol mencit pada kelompok perlakuan puasa Senin-Kamis menurun sebesar $0,55 \%$ jika dibandingkan dengan kelompok kontrol. Namun rata-rata kadar kolesterol mencit pada kelompok perlakuan puasa Daud mengalami kenaikan jika dibandingkan dengan kelompok kontrol yaitu sebesar 0,36\%.

Tabel 1. Rata-Rata Kadar Kolesterol Mencit

\begin{tabular}{|c|c|c|}
\hline Perlakuan & n (ekor) & Kadar kolesterol $(\mathrm{mg} / \mathrm{dL}) \pm \mathrm{SD}$ \\
\hline Tidak puasa (kontrol) & 6 & $168,00 \pm 64,21$ \\
\hline Puasa Senin-Kamis & 6 & $112,67 \pm 06,35$ \\
\hline Puasa Daud & 6 & $204,33 \pm 82,09$ \\
\hline
\end{tabular}

Keterangan : $\mathrm{a}=$ Tidak ada perbedaan yang signifikan pada taraf $5 \%$

$\mathrm{n}=$ Jumlah hewan coba

$\mathrm{SD}=$ Standar Deviasi

Menurut penelitian Triliana dan Airlangga (2018), puasa dapat menyebabkan penurunan kadar LDL pada darah sehingga puasa merupakan salah satu cara yang dapat dilakukan jika ingin menghindari hiperkolesterolemia atau kadar kolesterol darah yang berlebihan. Pada penelitian ini, pernyataan tersebut sesuai dengan hasil dari perlakuan berupa puasa Senin-Kamis. Sedangkan hasil dari perlakuan puasa Daud tidak sesuai dengan penelitian Triliana dan Airlangga (2018). Kenaikan kadar kolesterol mencit pada perlakuan puasa Daud disebabkan karena menurut pengamatan, mencit yang dipuasakan Daud mengalami perbaikan nafsu makan. Hal ini ditunjukkan dengan mencit yang dipuasakan Daud selalu menghabiskan makanan ketika mereka diberi makanan setelah sore sampai pagi hari sebelum mereka dipuasakan kembali. Sangat berbeda dengan kelompok kontrol yaitu mencit yang tidak puasa. Mereka cenderung membuang-buang makanan yang diberikan dan justru terlihat nafsu makan mereka menurun. Menurut 
Frandson (1992), salah satu faktor yang menyebabkan kenaikan kadar kolesterol dalam darah adalah faktor makanan. Semakin banyak makanan yang dikonsumsi apalagi makanan tersebut banyak mengandung kolesterol, maka akan menyebabkan peningkatan kadar kolesterol dalam darah.

\section{SIMPULAN}

Penelitian selanjutnya perlu untuk dilakukan misalnya dengan melakukan penelitian ini terhadap manusia. Hal ini dikarenakan puasa merupakan kegiatan yang lebih bersifat spiritual (berniat puasa secara sadar) sehingga kemungkinan kegiatan ini tidak memberikan dampak yang nyata pada hewan, ketika dilakukan pada manusia akan memberikan hasil yang berbeda. Selain itu, menambah lama waktu perlakuan perlu juga untuk diteliti. Hal ini dikarenakan perlakuan puasa adalah salah satu perlakuan yang hasilnya tidak langsung terlihat nyata seperti perlakuan menggunakan obat kimia. Dimungkinkan dengan menambah lama waktu perlakuan akan terlihat pengaruhnya terhadap kadar kolesterol semakin nyata (signifikan).

\section{DAFTAR PUSTAKA}

Fathonah, A.Y.N. 2011. Pelaksanaan Puasa Daud dan Hubunganya dengan Kestabilan Emosi (Santriwati PP. Al - Fitroh Jejeran Wonokromo Plered Bantul Yogyakarta) (skripsi). Yogyakarta: Universitas Islam Negeri Sunan Kalijaga.

Frandson, R.D. 1992. Anatomi dan Fisiologi Ternak. Edisi ke-4. Yogyakarta: Medical Publication.

Guyton, A.C. 1996. Buku Fisiologi Kedokteran. Edisi ke-7. Terjemahan K.A Engardi. Jakarta: EGC.

Harper, R.P; V.W. Rodwell dan P.A. Mayers. 1979. Review of Phisiological Chemistry. $17^{\text {th }}$ Edition. California: Lange Medical.

Hicow. 2011. Mengurangi Tingkat Kolesterol Menggunakan Zocor. (http://id.hicow.com/statin/ low-density-lipoprotein/simvastatin2791071.html, diakses 10 Oktober 2018). 
Irchamni, A. 2011. Pengaruh Intensitas Melakukan Puasa Senin Kamis terhadap Penurunan Tingkat Kecemasan Santri dalam Menghafal Nadham Alfiyah di Madrasah Diniyah Tsanawiyah "Mamba'ul Huda" Talok Woh Mojongawen Blora. (skripsi). Semarang: Institut Agama Islam Negeri Walisongo.

Judarmanto, W. 2012. 20 Mukjizat Puasa terhadap Kesehatan Manusia. (www.kompas.com, diakses tanggal 10 Januari 2017).

Kurniawati, A. 2010. Pengaruh Aktivitas Puasa Sunnah Dawud dan Senin-Kamis terhadap Motivasi Berprestasi pada Siswa Kelas XI MAN Temanggung Tahun Ajaran 2009/2010. (skripsi). Salatiga: STAIN Salatiga.

Murray, R.K., Granner, dan Rodwell. 2003. Biokimia Harper. Penerjemah Andry Hartono. Jakarta: EGC.

Panagiotakos, D.B. 2007. Abdominal Obesity, Blood Glucose and Apolipoprotein B Levels are The Best Predictors of The Incidence of Hypercholesterolemia (2001-2006) Among Healhty Adults: The ATTICA Study. Lipids in Health and Disease, 7(11):01-10.

Purwaningsih, Y. 2007. Pengaruh Puasa Senin-Kamis terhadap Suhu Tubuh Basal Santri Pondok Pesantren Nurul Umah Putri Kota Gede Yogyakarta sebagai Alternatif Sumber Belajar Biologi Sma Kelas XI. (skripsi). Yogyakarta: Universitas Islam Negeri Sunan Kalijaga.

Saleh, Marhamah. 2009. Faq, Fiqih Puasa, Risalah Puasa, I'tikaf.(https://marhamahsaleh.files.wordpress.com/2009/10/tanya-jawabpuasa.pdf, diakses tanggal 26 November 2018).

Saputra, A.B.W. 2016. Pengaruh Puasa Senin dan Kamis terhadap Kadar Gula Darah pada Penderita Diabetes Melitus Tipe 2 di Dukuh Kasihan, Bantul, Yogyakarta. (skripsi). Yogyakarta: Universitas Muhammadiyah Yogyakarta.

Susetya, W. 2007. Fungsi-fungsi Terapi Psikologis dan Medis di balik Puasa Senin Kamis. Yogyakarta: Diva Press.

Syarifuddin, A. 2003. Puasa Menuju Sehat Fisik dan Psikis. Jakarta: Gema Insani.

Tribunnews. 2016. Ciri-Ciri Kolesterol Tinggi dan Cara Mengatasinya.(http:/www.tribunnews.com/tribunners/2016/12/19/ciri-cirikolesterol-tinggi-dan-cara-mengatasinya, di akses tanggal 26 November 2018).

Triliana, R. dan H. Airlangga. 2018. Peran Gender dan Interval Puasa pada Profil Lipid Tikus Wistar dengan Diet Atherogenik. Jurnal Kesehatan Islam, 7(1): 57-62.

Waspaji, S. 2003. Pengkajian Status Gizi. Jakarta : FKUI. 